\title{
Neurotrophins and neuropathic pain in patients with traumatic brain injury
}

\author{
Jiseok Baik \\ Department of Anesthesia and Pain Medicine, Biomedical Research Institute, Pusan National University Hospital, Pusan National University School \\ of Medicine, Busan, Korea
}

Received December 9, 2019, Accepted December 9, 2019

Correspondence

Jiseok Baik

Department of Anesthesia and Pain Medicine, Biomedical Research Institute, Pusan National University Hospital, Pusan National University School of Medicine, 179 Gudeok-ro, Seo-gu, Busan 49241, Korea

Tel: +82-51-240-7399, Fax: +82-51-242-7466, E-mail: jidal75@naver.com

Traumatic brain injury (TBI) is a major health problem worldwide. It results in many deaths, much disability, and the consumption of substantial healthcare resources each year. Pain clinicians should do their best to avoid situations in which patients with TBI suffer from chronic pain for life and ultimately become chronic patients who require continuous medication, rehabilitation, or interventional treatment, even though they have been successfully revived in an emergency situation.

After the primary mechanical insult in patients with TBI, a cascade of secondary injuries often leads to further neural tissue loss [1]. The mechanisms underlying posttraumatic neuropathic pain are unclear, but they are most likely related to the regeneration process that occurs after the loss of neural tissue.

Neurotrophins regulate the survival, growth, and death of neurons [2]. The neurotrophin group comprises four members: nerve growth factor, brain-derived neurotrophic factor (BDNF), neurotrophin 3, and neurotrophin 4 [2]. Among these, BDNF not only promotes neuronal survival, growth, and death, but is also involved in synaptic plasticity and neurogenesis [3]. Further, BDNF is known to increase peripheral nerve regeneration and act as an endogenous regulator of pain response after spinal cord injury [4]. Many reports indicate that BDNF plays a locally important role in nociceptive pain as well as neuropathic pain development after nerve injury [4]; in addition, it is known to protect neurons against glutamate excitotoxicity [5].

Few studies have investigated BDNF levels in patients with TBI, and the results of these studies are inconsistent [5]. The serum level of BDNF on the day of traumatic injury is not only closely related to the diagnosis of TBI, but also provides information on the prognosis after 6 months [6]. Furthermore, evaluation of the BDNF level on the day of injury also helps in the stratification of risk for TBI [6].

The expression of the high affinity BDNF receptor tropomyosin receptor kinase B (TrkB) is regulated in the lumbar back muscle ganglion and spinal dorsal horn [2]. The flavonoid 7,8-dihydroxyflavone is known to function in a manner similar to BDNF as a TrkB agonist, and this analogue has recently been reported to have effects similar to those of BDNF with respect to promotion of neuronal survival and regeneration in TBI [1]. The ability to cross the blood-brain barrier of flavonoid 7,8-dihydroxyflavone has broad therapeutic potential in the central nervous system and suggests that it may be used as a useful compound in future TBIs and other neurological diseases [1]. (c) This is an open-access article distributed under the terms of the Creative Commons Attribution Non-Commercial License (http://creativecommons.org/licenses/by-nc/4.0/), which permits unrestricted non-commercial use, distribution, and reproduction in any medium, provided the original work is properly cited.

(C) The Korean Pain Society, 2020
Author contributions: Jiseok Baik: Writing/manuscript preparation. 
Research investigating BDNF and other neurotrophins is actively being conducted by many investigators in various fields, and members of the Korean Pain Society should take an interest in these studies. On the social front, establishing preventive and therapeutic guidelines may facilitate the successful return of patients with TBI to a productive life while easing the burden of the healthcare costs borne by society. As pain clinicians, we should maintain a focus on preventing chronic pain in patients with TBI.

\section{CONFLICT OF INTEREST}

No potential conflict of interest relevant to this article was reported.

\section{FUNDING}

This work was supported by the National Research Foundation of Korea (NRF) grant funded by the Korea government (Ministry of Science and ICT) (No. 2018R1C1B6 004841)

\section{ORCID}

Jiseok Baik, https://orcid.org/0000-0003-4904-7400

\section{REFERENCES}

1. Wurzelmann M, Romeika J, Sun D. Therapeutic potential of brain-derived neurotrophic factor (BDNF) and a small molecular mimics of BDNF for traumatic brain injury. Neural Regen Res 2017; 12: 7-12.

2. Khan N, Smith MT. Neurotrophins and neuropathic pain: role in pathobiology. Molecules 2015; 20: 10657-88.

3. Kowiański P, Lietzau G, Czuba E, Waśkow M, Steliga A, Moryś J. BDNF: a key factor with multipotent impact on brain signaling and synaptic plasticity. Cell Mol Neurobiol 2018; 38: 579-93.

4. Marcol W, Kotulska K, Larysz-Brysz M, Kowalik JL. BDNF contributes to animal model neuropathic pain after peripheral nerve transection. Neurosurg Rev 2007; 30: 235-43.

5. Almeida RD, Manadas BJ, Melo CV, Gomes JR, Mendes CS, Grãos MM, et al. Neuroprotection by BDNF against glutamate-induced apoptotic cell death is mediated by ERK and PI3-kinase pathways. Cell Death Differ 2005; 12: 1329-43.

6. Korley FK, Diaz-Arrastia R, Wu AH, Yue JK, Manley GT, Sair HI, et al. Circulating brain-derived neurotrophic factor has diagnostic and prognostic value in traumatic brain injury. J Neurotrauma 2016; 33: 215-25. 